\title{
Total arsenic and inorganic arsenic speciation and their correlation with fluoride, iron and manganese levels in groundwater intended for human consumption in Uruguay
}

\author{
I. Machado ${ }^{1}$, V. Bühl ${ }^{1} \&$ N. Mañay ${ }^{2}$ \\ ${ }_{1}^{1}$ Analytical Chemistry, Faculty of Chemistry, DEC, Universidad de la República (UdelaR), Montevideo, Uruguay \\ ${ }^{2}$ Toxicology, Faculty of Chemistry, DEC, Universidad de la República (UdelaR), Montevideo, Uruguay
}

\begin{abstract}
The aim of this study is to develop analytical methodologies for the assessment of total arsenic (As) and inorganic As species, fluoride, iron and manganese in groundwater samples used for human consumption in Uruguay, and to evaluate the possible correlations between them. For this, 50 samples of groundwater from north Uruguay were analyzed. The concentration ranges found were: $\mathrm{tAs}(0.94-58.9) \mu \mathrm{g} \mathrm{L}^{-1}, \mathrm{~F}^{-}(0.168-1.528) \mathrm{mg} \mathrm{L}-1, \mathrm{Fe}$ (2.1-95.5) $\mu \mathrm{g} \mathrm{L}^{-1}$, and $\mathrm{Mn}(0.12-138.6) \mu \mathrm{g} \mathrm{L}^{-1}$. More than half of the samples presented tAs concentration above WHO As limits for drinking water, with the corresponding risks for public health. Pearson correlations between tAs and $\mathrm{F}^{-}, \mathrm{Fe}$ and $\mathrm{Mn}$ were studied, resulting in strong positive correlations for $\mathrm{As} / \mathrm{F}^{-}$and $\mathrm{As} / \mathrm{Fe}$. Preliminary results showed higher As(III) levels in the samples, which is in agreement with the reducing conditions of the aquifers.
\end{abstract}

\section{INTRODUCTION}

Arsenic (As) levels in natural waters have been cited in different environments, although the highest concentrations were found in groundwaters, mainly linked to natural geochemical processes (Smedley \& Kinninburgh, 2002). In reducing aquifers, like those found in Uruguay, As(III) generally constitutes a high proportion of total As (tAs). Its mobilization is usually originated by desorption of mineral oxides and the reductive dissolution of $\mathrm{Fe}$ and $\mathrm{Mn}$ oxides. Since inorganic As (iAs) species present higher toxicity, especially As (III), it is important to carry out speciation analysis (Smedley et al., 2001).

Geogenic As in groundwater surveillance is recently conducted in Uruguay, and different aquifers of the country showed As levels above those recommended by WHO guidelines for drinking water $\left(10 \mu \mathrm{g} \mathrm{L}^{-1}\right)$ (WHO, 2017). The aim of this study is the development and optimization of analytical methodologies for the determination and assessment of tAs and iAs species, fluoride, iron and manganese in groundwater samples used for human consumption in Uruguay, as well as to evaluate the possible correlations between tAs and iAs with the mentioned inorganic parameters, of which, no systematic control studies are carried out.

\section{EXPERIMENTAL}

\subsection{Analytical determinations}

For analytical determinations of tAs, Fe and Mn by ETAAS, an atomic absorption spectrometer (iCE 3500, Thermo Scientific) equipped with a graphite furnace atomizer and Zeeman-based correction was employed. Argon ( $\mathrm{Ar} 99.99 \%$, Linde) was used as purge and protective gas. The analytical lines used were: $193.7 \mathrm{~nm}(\mathrm{As})$,
$302.1 \mathrm{~nm}(\mathrm{Fe})$ and $279.5 \mathrm{~nm}(\mathrm{Mn})$ and the signal used for quantification was integrated absorbance (peak-area). For all the determinations, pyrolytically coated graphite tubes (Thermo Scientific) were used (Table 1). For As determination palladium matrix modifier (Merck) was used $(5 \mu \mathrm{g})$ (Table 2).

For iAs speciation analysis, a continuous flow hydride generation system made in-house was employed. Ar (99.99\%, Linde) was used as carrier gas, with a flow rate of $75 \mathrm{~mL} \mathrm{~min}^{-1}$, controlled by means of a rotameter (Cole Parmer). Two T-pieces ( $0.8 \mathrm{~mm}$ inner bore) were

Table 1. ET-AAS temperature programs for tAs, Fe and Mn.

\begin{tabular}{llll}
\hline Parameter & $\begin{array}{l}\text { Temperature } \\
\left({ }^{\circ} \mathrm{C}\right)\end{array}$ & $\begin{array}{l}\text { Ramp rate } \\
\left({ }^{\circ} \mathrm{C} \mathrm{s}^{-1}\right)\end{array}$ & $\begin{array}{l}\text { Hold time } \\
(\mathrm{s})\end{array}$ \\
\hline $\begin{array}{l}\text { Drying } \\
\text { Pyrolysis }\end{array}$ & 100 & 10 & $50^{\mathrm{a}} / 30^{\mathrm{b}, \mathrm{c}}$ \\
Atomization & $2200^{\mathrm{a}} / 1100^{\mathrm{b}} / 2100^{\mathrm{b}} / 1800^{\mathrm{c}}$ & 150 & 20 \\
Cleaning & 2600 & 0 & 3 \\
\hline
\end{tabular}

a-As, b-Fe, c-Mn. Ar flow: $0.2 \mathrm{~mL} \mathrm{~min}^{-1}$, except during atomization step. Injection volume: $30 \mu \mathrm{L}$.

Table 2. Main figures of merit obtained by ET-AAS.

\begin{tabular}{llll}
\hline Parameter & As & Fe & Mn \\
\hline Linearity $\left(\mu \mathrm{g} \mathrm{L}^{-1}\right)$ & up to 20.0 up to 100 up to 3.0 \\
LOD $(3 \sigma, \mathrm{n}=10)\left(\mu \mathrm{g} \mathrm{L}^{-1}\right)$ & 0.27 & 0.54 & 0.032 \\
LOQ $(10 \sigma, \mathrm{n}=10)\left(\mu \mathrm{g} \mathrm{L}^{-1}\right)$ & 0.90 & 1.8 & 0.11 \\
Precision (RSD, $\mathrm{n}=10)$ & \multicolumn{4}{c}{$\leq 10 \%$} \\
Trueness (compared to & $98-102 \%$ & $99-101 \%$ & $99-103 \%$
\end{tabular}

Certified value, $n=6)^{*}$

*CRM NIST: SRM 1643f Trace elements in water 
used to merge sample flow with reductant flow and, downstream, to merge the reaction mixture flow with Ar flow. The outlet from a second T-piece was connected to a 3-mL internal volume gas-liquid separator with a forced outlet. Sample and reductant solutions were delivered by a peristaltic pump (RP-1 Dynamax). Sample and reductant flow rates were $4.0 \mathrm{~mL} \mathrm{~min}^{-1}$ and $1.5 \mathrm{~mL} \mathrm{~min}^{-1}$ respectively. The system was coupled to a flame atomic absorption spectrometer (AAnalyst 200, Perkin Elmer). An EDL lamp (Perkin Elmer) operated at $193.7 \mathrm{~nm}$ was used. The quartz T-tube cell with a path-length of $165 \mathrm{~mm}$ and a diameter of $12 \mathrm{~mm}$, was heated to $980^{\circ} \mathrm{C}$ by an acetyleneair flame. The previous separation of the species was achieved by a liquid chromatograph (LC-20AT Prominence Shimadzu) working in isocratic mode, equipped with a Dionex IonPac AS22 $(4 \times 250 \mathrm{~mm})$ column, using $60 \mathrm{mM} \mathrm{NH}_{4} \mathrm{H}_{2} \mathrm{PO}_{4}$ solution adjusted to $\mathrm{pH} 5.8$ as mobile phase at $1.5 \mathrm{~mL} \mathrm{~min}^{-1}$.

Fluoride $\left(\mathrm{F}^{-}\right)$concentrations were measured by a combined fluoride electrode connected to a $\mathrm{pH} /$ ion meter (Orion VersaStar Thermo Scientific). Total ionic strength adjustment buffer TISAB II (Orion Thermo Scientific) was used. For each measurement, $50 \mathrm{~mL}$ of sample were mixed with $10 \mathrm{~mL}$ of TISAB II solution.

\subsection{Reagents}

All chemicals used were of analytical reagent grade and all the solutions were prepared with ultrapure water of $18.2 \mathrm{M} \Omega \mathrm{cm}$ resistivity (ASTM Type I).

All glassware was soaked overnight in $10 \%(\mathrm{v} / \mathrm{v})$ $\mathrm{HNO}_{3}$ before use. For the preparation of calibration curves, commercial standard solutions $\left(1000 \mathrm{mg} \mathrm{L}^{-1}\right)$ of $\mathrm{As}(\mathrm{V}), \mathrm{Fe}$ and Mn (Merck) were used, as well as sodium arsenite $\left(\mathrm{NaAsO}_{2} 99.0 \%\right.$, Sigma-Aldrich) and sodium fluoride ( $\mathrm{NaF} 99.5 \%$, Merck).

\subsection{Samples}

A total of 50 groundwater samples were collected from different points of the north part of Uruguay at depths between 40 and $50 \mathrm{~m}$. The $\mathrm{pH}$ of the samples was adjusted with $\mathrm{HCl}$ to 2.0 in order to prevent interchanges between As species. Samples were stored in polypropylene bottles at $4-5^{\circ} \mathrm{C}$.

\section{RESULTS}

\section{1 t As, iAs, $F^{-}, \mathrm{Fe}$ and Mn levels in the samples}

The tAs concentration values found in the groundwater samples, ranged from 0.94 to $58.9 \mu \mathrm{g} \mathrm{L}^{-1}$. More than half of the samples ( 27 samples) were above those recommended by WHO $\left(10 \mu \mathrm{g} \mathrm{L}^{-1}\right)$ for drinking water. The high concentrated sample $\left(58.9 \mu \mathrm{g} \mathrm{L}^{-1}\right)$ was taken from an area located at the northwest part of the country called "Salto Grande" which corresponds to a zone of thermal waters that emanates at $45^{\circ} \mathrm{C}$ from a depth of $1295 \mathrm{~m}$. This relatively high natural concentration may be associated only to mineral components of the geological framework, since there is no mining activity in this area.
The iAs determinations are still on process, but preliminary results showed higher As(III) levels in the samples, which is in agreement with the reducing conditions of the aquifers.

Total concentration values of $\mathrm{Fe}$ and $\mathrm{Mn}$ in the samples, ranged from 2.1 to $95.5 \mu \mathrm{g} \mathrm{L}^{-1}$ and from 0.12 to $138.6 \mu \mathrm{g} \mathrm{L}^{-1}$ respectively. $\mathrm{F}^{-}$values ranged from 0.168 to $1.528 \mathrm{mg} \mathrm{L}^{-1}$. The sample from "Salto Grande" also presented the highest $\mathrm{F}^{-}$value, exceeding the limit of $1.5 \mathrm{mg} \mathrm{L}^{-1}$ recommended by WHO. This could be related to natural geochemical processes such as the ion exchange with the increase of the precipitation of fluorite $\left(\mathrm{CaF}_{2}\right)$.

\subsection{Correlation of tAs with $F^{-}, \mathrm{Fe}$ and Mn levels}

Pearson correlation analysis of tAs with $\mathrm{F}^{-}$, Fe and $\mathrm{Mn}$ concentrations in the samples were performed, resulting in highly significant positive correlation coefficients $(\mathrm{p}<0.05)$ for $\mathrm{As} / \mathrm{F}^{-}(r=0.876)$ and $\mathrm{As} / \mathrm{Fe}(r=0.652)$. However, a negative correlation coefficient was found for $\mathrm{As} / \mathrm{Mn}(r=-0.206)$.

\section{CONCLUSIONS}

Groundwater analysis showed that in some sampled points As and $\mathrm{F}^{-}$concentrations were above those of WHO guidelines, being the highest values found in samples from the northwest part of the country. Also, strong positive Pearson correlations were found for these two elements.

The lack of knowledge of As in groundwater issues and its use as drinking water for human and animal consumption in Uruguay is a major area of interest in Medical Geology research in Uruguay, as there is also a lack of epidemiological studies on As exposure health risks. Arsenic levels in groundwater and its relationship with other elements, should be deeply studied to prevent long-term health effects.

The results of this ongoing study will contribute not only to the understanding of the As situation of groundwater in Uruguay, but also to expand the existing information on the distribution of As species in the regions of the world.

\section{ACKNOWLEDGEMENTS}

The authors thank PEDECIBA-Química.

\section{REFERENCES}

Smedley, P.L., Kinniburgh, D.G., Huq, I., Zhen-dong, L. \& Nicolli, H.B. 2001. In W.R. Chappell, C.O. Abernathy \& R.L. Calderon (eds), Arsenic Exposure and Health Effects $I V:$ 467-450. New York: Elsevier Science Ltd.

Smedley, P.L. \& Kinniburgh, D.G. 2002. A review of the source, behavior and distribution of arsenic in natural waters. Appl. Geochem. 17: 517-568.

WHO. 2017. Guidelines for drinking-water quality: Fourth edition incorporating the first addendum. Geneva. 